\title{
Plantlet Regeneration and Multiple Shoot Induction from Protocorm- Like Bodies (PLBs) of Medicinal Orchid Species, Dendrobium crumenatum Sw.
}

\author{
Sutha KLAOCHEED ${ }^{1, *}$, Suphat RITTIRAT ${ }^{2}$ and Kanchit THAMMASIRI ${ }^{3}$ \\ ${ }^{1}$ Department of Technology and Industries, Faculty of Science and Technology, \\ Prince of Songkla University, Pattani campus, Pattani 94000, Thailand \\ ${ }^{2}$ Faculty of Science and Technology, Nakhon Si Thammarat Rajabhat University, \\ Nakhon Si Thammarat 80280, Thailand \\ ${ }^{3}$ Department of Plant Science, Faculty of Science, Mahidol University, Bangkok 10400, Thailand
}

('Corresponding author's e-mail: sutha.psu@gmail.com)

Received: 20 November 2019, Revised: 20 May 2020, Accepted: 20 June 2020

\begin{abstract}
To investigate the suitable medium for in vitro shoot regeneration and plantlet growth of Dendrobium crumenatum Sw., individual protocorm-like bodies (PLBs) (about 4 - $5 \mathrm{~mm}$ in diameter) of Dendrobium crumenatum Sw. derived from MS medium supplemented with $0.5 \mathrm{mg} / \mathrm{L}$ TDZ for 60 days of culture were cultured on 6 culture media; Murashige and Skoog (MS) medium, MS medium supplemented with $15 \%(\mathrm{v} / \mathrm{v}) \mathrm{CW}$, MS medium supplemented with $15 \%(\mathrm{v} / \mathrm{v}) \mathrm{CW}$ and $0.2 \%(\mathrm{w} / \mathrm{v}) \mathrm{AC}$, Vacin and Went (VW) medium, VW medium supplemented with $15 \%(\mathrm{v} / \mathrm{v}) \mathrm{CW}$, VW medium supplemented with $15 \%(\mathrm{v} / \mathrm{v}) \mathrm{CW}$ and $0.2 \%(\mathrm{w} / \mathrm{v})$ AC. After 4 months of culture, MS medium containing $15 \%$ coconut water $(\mathrm{CW})$ gave the highest percentage of shooting and number of shoots per explant of 96.0 and 9.5, respectively with a significant difference from other media. The addition of $0.2 \%$ $(\mathrm{w} / \mathrm{v})$ activated charcoal (AC) significantly increased the number of leaves and roots. PLBs developed into complete plantlets. MS medium supplemented with $15 \%(\mathrm{v} / \mathrm{v}) \mathrm{CW}$ and $0.2 \%(\mathrm{w} / \mathrm{v}) \mathrm{AC}$ and $\mathrm{VW}$ medium supplemented with $15 \%(\mathrm{v} / \mathrm{v}) \mathrm{CW}$ and $0.2 \%(\mathrm{w} / \mathrm{v}) \mathrm{AC}$ gave the highest number of roots per plantlet and root length at 5.3 roots and $34.9 \mathrm{~mm}$, respectively. After the transfer of rooted shoots to the greenhouse, $95 \%$ of the regenerated plantlets survived and grew vigorously. Plantlets grown in vitro were successfully acclimatized in the greenhouse and showed normal development.
\end{abstract}

Keywords: Dendrobium crumenatum, Germplasm conservation, In vitro conservation, Micropropagation, Thidiazuron

\section{Introduction}

The Orchidaceae represents approximately $10 \%$ of angiosperms. It is one of the largest, most diverse, and most important categories of botanically and commercially significant flowering plants with 20,000 - 30,000 species [1,2]. The floral characteristics of orchids cover an exceptionally wide range of different shapes, forms, sizes, and colorations, surpassing flowers of all the other angiosperms.

Dendrobium crumenatum Sw., commonly called pigeon orchid, is a member of the family Orchidaceae. It is native to India, Indochina, Taiwan, the Philippines, Malaysia, Indonesia, New Guinea, and Christmas Island. It is reportedly naturalized in Fiji, Hawaii, the West Indies, and the Seychelles. It grows in many localities from full sun to deep shade. Dendrobium crumenatum Sw. produces upright, sympodial, pseudobulbs that are swollen at the first 3 or 4 bottom nodes. The middle portion carries the leaves of $7 \mathrm{~cm}$ long and $2 \mathrm{~cm}$ wide that is very leathery. The top portion of the pseudobulbs carries flowers of about $2.5 \mathrm{~cm}$ 
and pure white, with yellow markings on the labellum. The bloom cycle is triggered 9 days after a sudden drop in temperature, usually as a result of rain, although the same effect can be artificially created. $D$. crumenatum Sw. flowers are fragrant, but the scent lasts only for 1 day $[3,4]$.

This orchid is valuable for its medicinal properties exhibiting antimicrobial activity [5]. Given the importance of $D$. crumenatum Sw., mass propagation for commercial cultivation requires a simple, economical, rapidly multiplying, and highly reproducible protocol. The present study was carried out to select the appropriate medium for shoot regeneration and plantlet development of D. crumenatum Sw. from calli-derived protocorm-like bodies (PLBs) under in vitro conditions and consequently on the ex vitro acclimatization process.

\section{Materials and methods}

\section{Plant materials and surface sterilization}

Main shoots of $D$. crumenatum Sw. (15 - $25 \mathrm{~cm}$ long) were harvested from plants grown in the greenhouse at the Faculty of Science and Technology, Nakhon Si Thammarat Rajabhat University. The stalks were cut into the nodal segments, each holding 1 axillary bud. Surface sterilization of nodal segments (about 3 - $4 \mathrm{~cm}$ in length) was performed according to Meesawat and Kanchanapoom [6]. The sterilized $D$. crumenatum Sw. buds were cultured on MS medium supplemented with $3 \%(\mathrm{w} / \mathrm{v})$ sucrose, a combination of $1.0 \mathrm{mg} / \mathrm{L} \mathrm{BA}$ and $0.1 \mathrm{mg} / \mathrm{L} \mathrm{NAA,} 0.2 \%(\mathrm{w} / \mathrm{v})$ peptone, and $0.2 \%(\mathrm{w} / \mathrm{v}) \mathrm{AC}$ at $\mathrm{pH} 5.7$ to initiate callus from the modified method as described by Meesawat and Kanchanapoom [6]. The callus proliferation was observed after 1 month of culture. These calli were then transferred to the same medium. The subculture monthly was recommended to produce more totipotent calli than the subsequent experiment. For protocorm-like bodies (PLBs) formation, calli at 1 month of culture were transferred to MS medium supplemented with $0.5 \mathrm{mg} / \mathrm{L}$ Thidiazuron (TDZ) for 60 days of culture from the method as described by Rittirat et al. [7].

Influence of different basal media on in vitro shoot regeneration and plantlet growth of Dendrobium crumenatum Sw. after culture for 4 months

To investigate the suitable medium for in vitro shoot regeneration and plantlet growth of Dendrobium crumenatum Sw., individual protocorm-like bodies (PLBs) (about $4-5 \mathrm{~mm}$ in diameter) of Dendrobium crumenatum Sw. derived from MS medium supplemented with $0.5 \mathrm{mg} / \mathrm{L}$ TDZ for 60 days of culture (Figure 2) [7] were cultured on 6 culture media; Murashige and Skoog [8] (MS) medium, MS medium supplemented with $15 \%(\mathrm{v} / \mathrm{v}) \mathrm{CW}$, MS medium supplemented with $15 \%(\mathrm{v} / \mathrm{v}) \mathrm{CW}$ and $0.2 \%$ (w/v) AC, Vacin and Went (VW) [9] medium, VW medium supplemented with $15 \%(\mathrm{v} / \mathrm{v}) \mathrm{CW}$, VW medium supplemented with $15 \%(\mathrm{v} / \mathrm{v}) \mathrm{CW}$ and $0.2 \%(\mathrm{w} / \mathrm{v}) \mathrm{AC}$.

The culture media were solidified with $0.75 \%(\mathrm{w} / \mathrm{v})$ agar-agar (commercial grade). The $\mathrm{pH}$ of MS [8] and VW medium [9] was adjusted to 5.7 and 5.0, respectively with $1 \mathrm{~N} \mathrm{KOH}$ or $1 \mathrm{~N} \mathrm{HCl}$ prior to autoclaving for $15 \mathrm{~min}$ at $121^{\circ} \mathrm{C}$. The coconut water was taken out from the green coconut and added to the basal medium. All cultures were maintained at $25 \pm 2{ }^{\circ} \mathrm{C}$ under a $16 \mathrm{~h}$ photoperiod with light supplied by cool-white fluorescent lamps at an intensity of $10 \mu \mathrm{mol} \mathrm{m} \mathrm{m}^{-2} \mathrm{~s}^{-1}$ photosynthetic photon flux density (PPFD). The percentage of shooting, number of shoots per explant, number of leaves per explant, leaf length, leaf width, percentage of rooting, number of roots per explant, and root length were recorded and statistically compared after 4 months of culture

\section{Transplantation of plantlets/greenhouse acclimatization}

The complete plantlets derived from MS medium supplemented with $15 \%$ (v/v) CW and $0.2 \%$ (w/v) AC for 4 months of culture were taken out from culture bottles and rinsed thoroughly with tap water to remove residual nutrients and agar from the plantlets without causing damage to roots. These plantlets were treated with $0.1 \%$ fungicide (bavistin) solution for $5 \mathrm{~min}$ and again washed with sterile water. All plantlets were blot dried and then transplanted to pots containing sterilized coconut husks. All plantlets were grown in the greenhouse with $70-80 \%$ relative humidity and about $12 \mathrm{~h}$ photoperiod, 300 - $400 \mu \mathrm{mol} \mathrm{m} \mathrm{m}^{-2} \mathrm{~s}^{-1}$ photosynthetic photon flux density (PPFD) (shaded sunlight) and $33 \pm 2{ }^{\circ} \mathrm{C}$ to $30 \pm 2$ 
${ }^{\circ} \mathrm{C}$ day/night temperature. The young plants were sprayed with water twice a day for 2 months. The percentage of plantlet survival was recorded.

\section{Experimental design and statistical analysis}

All the experiments were conducted in a completely randomized design (CRD) with 5 replicates per treatment and the experiments were repeated 3 times. The results are expressed as mean $\pm \mathrm{SE}$ of 3 experiments. The data were analyzed by ANOVA using SPSS version 20 and the mean values were separated using Duncan's multiple range test (DMRT) at a $5 \%$ probability level.

\section{Results and discussion}

Influence of different basal media on in vitro shoot regeneration and plantlet growth of Dendrobium crumenatum Sw. after 4 months of culture

To investigate the suitable medium for in vitro shoot regeneration and plantlet growth of Dendrobium crumenatum Sw., individual protocorm-like bodies (PLBs) (about $4-5 \mathrm{~mm}$ in diameter) of Dendrobium crumenatum Sw. derived from MS medium supplemented with $0.5 \mathrm{mg} / \mathrm{L}$ TDZ for 60 days of culture were cultured on 6 culture media.

In this present study, PLBs produced green friable calli when cultured on MS or VW medium supplemented with $15 \%(\mathrm{v} / \mathrm{v}) \mathrm{CW}$ and $0.2 \%(\mathrm{w} / \mathrm{v}) \mathrm{AC}$ after 2 months of culture. Among the 6 media tested, the MS medium supplemented with $15 \%(\mathrm{v} / \mathrm{v}) \mathrm{CW}$ had the highest shooting percentage $(96.0 \%)$ when compared to the MS medium supplemented with $15 \%(\mathrm{v} / \mathrm{v}) \mathrm{CW}$ and $0.2 \%(\mathrm{w} / \mathrm{v}) \mathrm{AC}(56.0 \%)$, the VW medium supplemented with $15 \%(\mathrm{v} / \mathrm{v}) \mathrm{CW}(41.0 \%)$, the VW medium supplemented with $15 \%$ $(\mathrm{v} / \mathrm{v}) \mathrm{CW}$ and $0.2 \%(\mathrm{w} / \mathrm{v}) \mathrm{AC}(11.0 \%)$, the MS medium $(0.0 \%)$ and the VW medium (0.0\%). The PLBs were pale green to yellow when they were cultured on MS medium without $15 \%(\mathrm{v} / \mathrm{v}) \mathrm{CW}$ and $0.2 \%$ (w/v) AC. Similar results were found in VW medium without $15 \%(\mathrm{v} / \mathrm{v}) \mathrm{CW}$ and $0.2 \%(\mathrm{w} / \mathrm{v}) \mathrm{AC}$. However, these PLBs died after 4 months of culture (Table 1). MS medium supplemented with $15 \%$ $(\mathrm{v} / \mathrm{v}) \mathrm{CW}$ gave the highest percentage of shooting and number of shoots per explant of 96.0 and 9.5 , respectively (Table 1). A statistically significant difference was observed among treatments. The percentage of responding shooting was significantly lower $(p \leq 0.05)$ on MS or VW medium (Table 1).

This study was undertaken to evaluate the growth of D. crumenatum Sw. PLBs as influenced by 6 commonly used culture media in orchid. Our results showed that MS medium was superior to VW medium and both media containing $15 \%(\mathrm{v} / \mathrm{v}) \mathrm{CW}$ gave better results than those without $\mathrm{CW}$. CW is known to act like a cytokinin substance, hence promote cell division and growth of the protocorms [10].

Organic supplements have been shown to stimulate seed germination and seedling growth of many orchids [11-14]. However, their effects are complex and may vary depending on species, the types of explants or the developmental stages. In Cypripedium macranthos, as compared to coconut water, the potato and banana homogenates appeared to have a significant influence on the seedlings growth [15]. The presence of coconut water improved seed germination of Cypripedium species [16,17], but its nutrient compositions might be not sufficient for the subsequent growth of Cypripedium macranthos seedlings. 

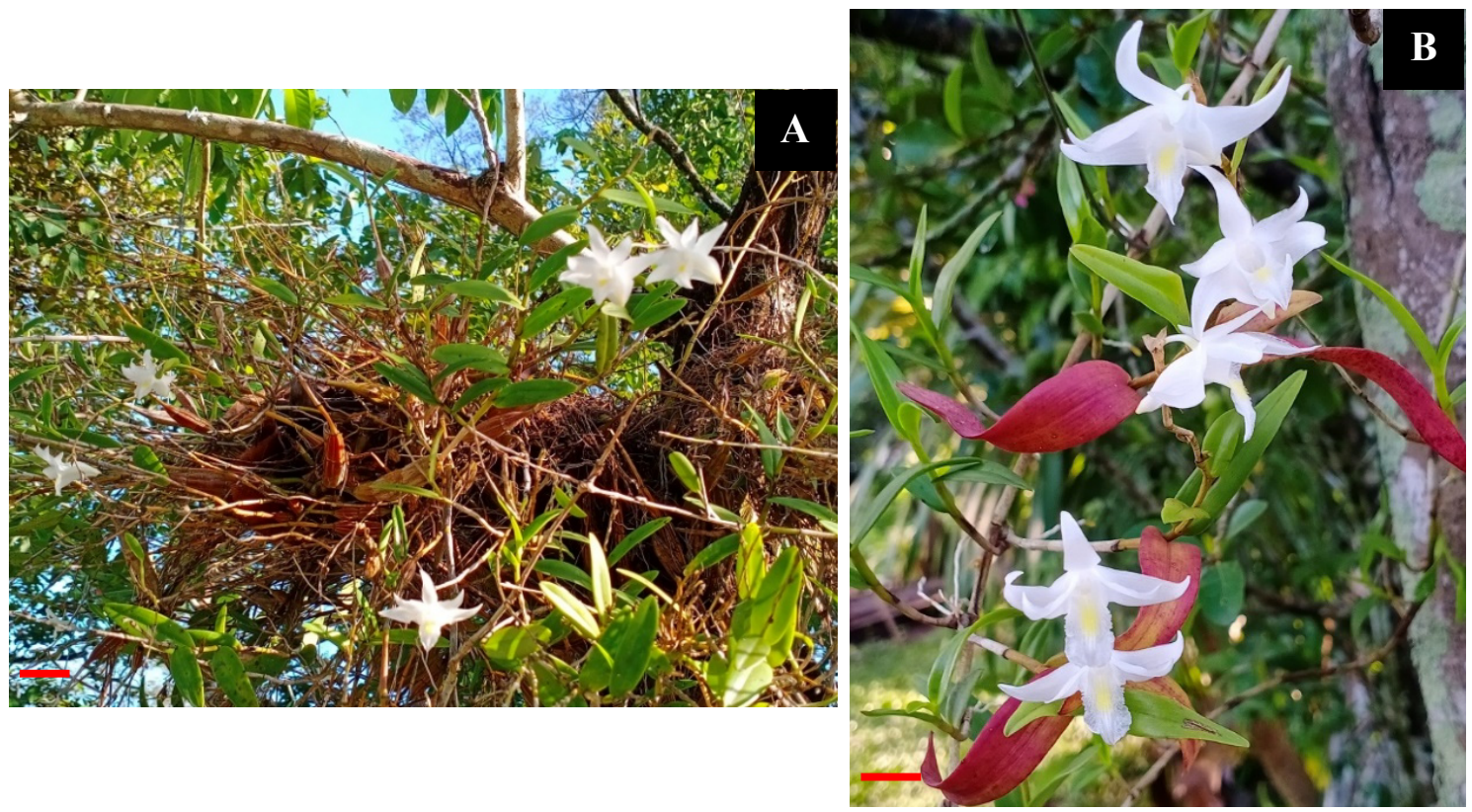

Figure 1 Dendrobium crumenatum Sw. plants growing in natural habitat. (A); Mature plants of D. crumenatum $\mathrm{Sw}$. and (B); flowers of $D$. crumenatum $\mathrm{Sw}$. showing pure glittering white and a bright yellow disc on the lip. (Scale bar, $\mathrm{A}=3 \mathrm{~cm}$ and $\mathrm{B}=1 \mathrm{~cm}$ ).
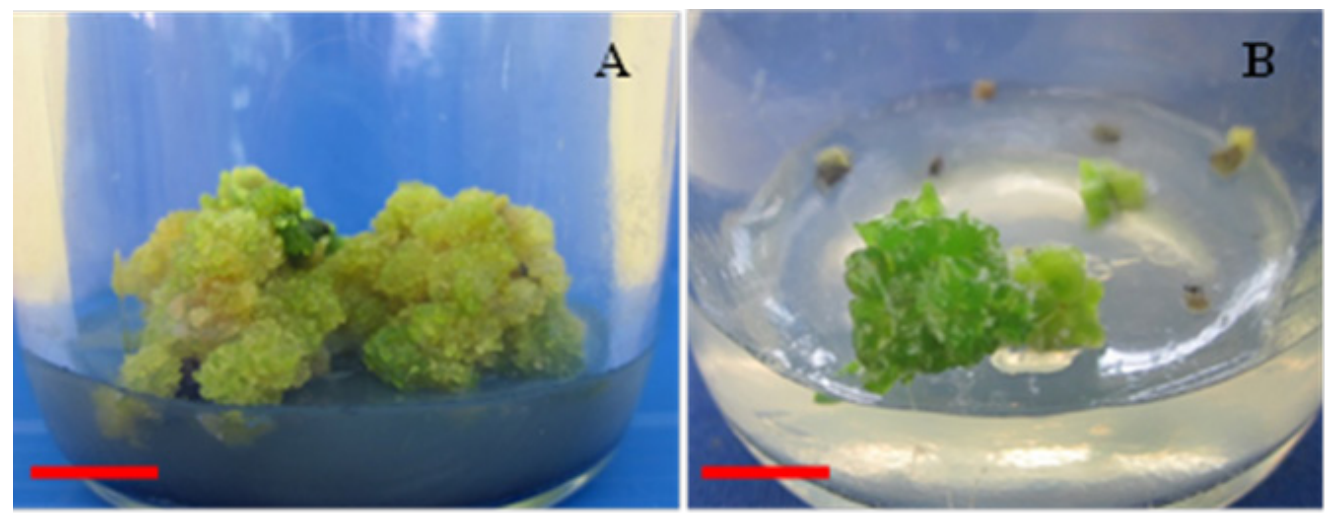

Figure 2 In vitro propagation of Dendrobium crumenatum Sw. (A); callus derived from explant on MS medium containing $3 \%(\mathrm{w} / \mathrm{v})$ sucrose and $0.76 \%(\mathrm{w} / \mathrm{v})$ agar (commercial grade), combination of 1.0 $\mathrm{mg} / \mathrm{L} \mathrm{BA}$ and $0.1 \mathrm{mg} / \mathrm{L} \mathrm{NAA}, 0.2 \%(\mathrm{w} / \mathrm{v})$ peptone and $0.2 \%(\mathrm{w} / \mathrm{v}) \mathrm{AC}$ and $(\mathbf{B})$; initiation of PLBs on calli cultured on MS medium supplemented with $0.5 \mathrm{mg} / \mathrm{L}$ TDZ for 60 days. (Scale bar $=1 \mathrm{~cm}$ ). 
Table 1 Influence of different basal media on in vitro shoot regeneration of Dendrobium crumenatum Sw. after 4 months of culture.

\begin{tabular}{lcccrc}
\hline \multicolumn{1}{c}{ Basal media } & $\begin{array}{c}\text { Shooting } \\
(\%)\end{array}$ & $\begin{array}{c}\text { No. of shoots } \\
\text { per explant } \\
(\text { mean } \pm \text { SE) })^{\mathrm{a}}\end{array}$ & $\begin{array}{c}\text { No. of leaves } \\
(\mathbf{m e a n} \pm \mathbf{S E})^{\mathrm{a}}\end{array}$ & $\begin{array}{c}\text { Leaf length } \\
(\mathbf{m m}) \\
(\mathbf{m e a n} \pm \mathbf{S E})^{\mathrm{a}}\end{array}$ & $\begin{array}{c}\text { Leaf width } \\
(\mathbf{m m})\end{array}$ \\
$(\mathbf{m e a n} \pm \mathbf{S E})^{\mathrm{a}}$ \\
\hline $\mathrm{MS}$ & $0.0^{\mathrm{c}}$ & $0.0 \pm 0.0^{\mathrm{c}}$ & $0.0 \pm 0.0^{\mathrm{c}}$ & $0.0 \pm 0.0^{\mathrm{c}}$ & $0.0 \pm 0.0^{\mathrm{c}}$ \\
$\mathrm{MS}+15 \% \mathrm{CW}$ & $96.0^{\mathrm{a}}$ & $9.5 \pm 0.4^{\mathrm{a}}$ & $3.8 \pm 0.2^{\mathrm{b}}$ & $28.2 \pm 0.9^{\mathrm{a}}$ & $8.9 \pm 0.4^{\mathrm{a}}$ \\
$\mathrm{MS}+15 \% \mathrm{CW}+0.2 \% \mathrm{AC}$ & $56.0^{\mathrm{b}}$ & $3.8 \pm 0.2^{\mathrm{b}}$ & $5.0 \pm 0.3^{\mathrm{a}}$ & $26.8 \pm 0.9^{\mathrm{a}}$ & $5.3 \pm 0.2^{\mathrm{b}}$ \\
$\mathrm{VW}$ & $0^{\mathrm{c}}$ & $0.0 \pm 0.0^{\mathrm{c}}$ & $0.0 \pm 0.0^{\mathrm{c}}$ & $0.0 \pm 0.0^{\mathrm{c}}$ & $0.0 \pm 0.0^{\mathrm{c}}$ \\
$\mathrm{VW}+15 \% \mathrm{CW}$ & $41.0^{\mathrm{b}}$ & $4.0 \pm 0.3^{\mathrm{b}}$ & $3.3 \pm 0.3^{\mathrm{b}}$ & $17.7 \pm 0.3^{\mathrm{b}}$ & $5.3 \pm 0.2^{\mathrm{b}}$ \\
$\mathrm{VW}+15 \% \mathrm{CW}+0.2 \% \mathrm{AC}$ & $11.0^{\mathrm{c}}$ & $4.0 \pm 0.5^{\mathrm{b}}$ & $3.2 \pm 0.2^{\mathrm{b}}$ & $20.6 \pm 0.6^{\mathrm{b}}$ & $5.6 \pm 1.7^{\mathrm{b}}$ \\
\hline
\end{tabular}

Means followed by different letters within the column are significantly different from others at $5 \%$ level by DMRT.

${ }^{\mathrm{a}}$ Values represent means \pm standard error.

For the rooting of shoots, MS or VW medium fortified with $15 \%(\mathrm{v} / \mathrm{v}) \mathrm{CW}$ or $15 \%(\mathrm{v} / \mathrm{v}) \mathrm{CW}$ and $0.2 \%(\mathrm{w} / \mathrm{v}) \mathrm{AC}$ were used (Table 2). Significant rooting response was observed in MS or VW medium containing $15 \%(\mathrm{v} / \mathrm{v}) \mathrm{CW}$ or $15 \%(\mathrm{v} / \mathrm{v}) \mathrm{CW}$ and $0.2 \%(\mathrm{w} / \mathrm{v}) \mathrm{AC}$ (Table 2). Among different treatments, the highest number of roots was observed in MS medium containing $15 \% \mathrm{CW}$ and $0.2 \% \mathrm{AC}$ with the average value of 5.3 per explant. The highest root length was observed in the VW medium containing 15 $\% \mathrm{CW}$ and $0.2 \% \mathrm{AC}(34.9 \mathrm{~mm})$ (Table 2). However, in support of the present finding, superiority of AC in root induction was also reported by [18]. Thus, among the different rooting media, AC was found to be most effective for the rooting of shoots of $D$. crumenatum Sw. This result was contrary to the previous findings of rooting in Aerides odorata [19] and Micropera pallida [20] showing a positive response in medium with IAA. Similarly, Pradhan [21] and Asghar et al. [22] observed a maximum number of roots on medium fortified with IBA than in NAA in orchid species.

Table 2 Mean response of plantlet growth to basal media of Dendrobium crumenatum Sw. after 4 months of culture.

\begin{tabular}{lccc}
\hline \multicolumn{1}{c}{ Basal media } & $\begin{array}{c}\text { Rooting } \\
(\%)\end{array}$ & $\begin{array}{c}\text { No. of roots per explant } \\
(\text { mean } \pm \mathbf{S E})^{\mathbf{a}}\end{array}$ & $\begin{array}{c}\text { Root length (mm) } \\
(\mathbf{m e a n} \pm \mathbf{S E})^{\mathrm{a}}\end{array}$ \\
\hline $\mathrm{MS}$ & $0.00^{\mathrm{c}}$ & $0.0 \pm 0.0^{\mathrm{d}}$ & $0.0 \pm 0.0^{\mathrm{e}}$ \\
$\mathrm{MS}+15 \% \mathrm{CW}$ & $70.00^{\mathrm{b}}$ & $3.0 \pm 1.3^{\mathrm{c}}$ & $24.0 \pm 0.2^{\mathrm{d}}$ \\
$\mathrm{MS}+15 \% \mathrm{CW}+0.2 \% \mathrm{AC}$ & $90.00^{\mathrm{a}}$ & $5.3 \pm 0.2^{\mathrm{a}}$ & $30.9 \pm 0.3^{\mathrm{b}}$ \\
VW & $0.00^{\mathrm{c}}$ & $0.0 \pm 0.0^{\mathrm{d}}$ & $0.0 \pm 0.0^{\mathrm{e}}$ \\
VW $+15 \% \mathrm{CW}$ & $70.00^{\mathrm{b}}$ & $3.7 \pm 0.2^{\mathrm{b}}$ & $28.5 \pm 0.2^{\mathrm{c}}$ \\
VW $+15 \% \mathrm{CW}+0.2 \% \mathrm{AC}$ & $90.00^{\mathrm{a}}$ & $3.9 \pm 0.2^{\mathrm{b}}$ & $34.9 \pm 0.3^{\mathrm{a}}$ \\
\hline
\end{tabular}

Means followed by different letters within the column are significantly different from others at $5 \%$ level by DMRT.

${ }^{\mathrm{a}}$ Values represent means \pm standard error. 
AC often promotes orchid shoot proliferation. AC has been reported to promote multiple shoot formation in nodal segments of $A$. formosanus [23]. AC has beneficial and harmful effects in the culture medium, depending upon the medium, explant, and plant-growth regulators used. The beneficial effects of $\mathrm{AC}$ on tissue responses in vitro could be attributed to:

1. providing a dark environment by darkening the medium [24];

2. adsorption of harmful substances produced by either the media or explant [25,26];

3. adsorption of plant-growth regulators and other organic compounds [27-29]; or

4. release of substances naturally present in or adsorbed by AC [30-32].

Hardening of the plants in the greenhouse under high humidity conditions was found to be highly beneficial for successful acclimatization. Well-developed in vitro derived shoots along with roots were transferred into sterilized coconut husks for ex vitro establishment of D. crumenatum Sw. Ninety-five percent of the regenerated plantlets survived and grew vigorously. Plantlets grown in vitro were successfully acclimatized in the greenhouse and showed normal development (Figure 3).

The ultimate success of micropropagation depends on acclimatization. During this period, a higher percentage of plant losses occur due to several reasons [33]. Therefore, it is necessary to obtain quality plantlets under in vitro conditions to ensure a high survival percentage and appropriate growth under greenhouse conditions. In order to survive ex vitro, a plantlet must achieve a growth stage with an appropriate sprout number, foliage area, and radicular system, considering roots number and length [34]. The successful rooting of the shoots and the number of roots per shoot are the key factors for acclimatization of Dendrobium crumenatum Sw. plantlets. Improvement of in vitro rooting techniques and conditions will facilitate the production of a greater number of roots and overall healthy plantlets which helps in better survival of plantlets upon transferring them to ex vitro conditions [35].

The transplantation stage continues to be a major bottleneck in the micropropagation of orchid. A substantial number of micro propagated plantlets fail to survive when transferred from in vitro conditions to a greenhouse or field environment. The greenhouse or field environment have substantially lower relative humidity, higher and intense light levels that are stressful to micro propagated plants compared to in vitro conditions [36].

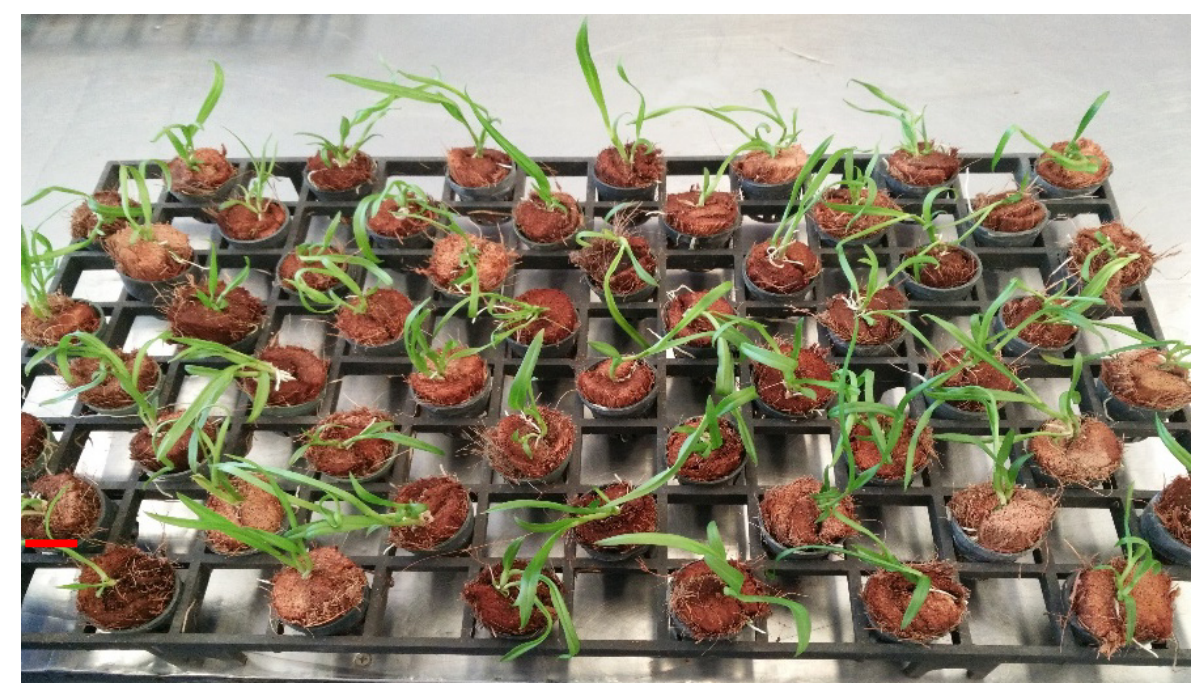

Figure 3 Dendrobium crumenatum Sw.; the complete plantlets derived from MS medium supplemented with $15 \%(\mathrm{v} / \mathrm{v})$ coconut water $(\mathrm{CW})$ and $0.2 \%(\mathrm{w} / \mathrm{v})$ activated charcoal (AC) for 4 months of culture with well-expanded leaves in pots containing sterilized coconut husks after 2 months of transplanting. $($ Scale bar $=1 \mathrm{~cm})$. 
A simple and easy technique for the medium-term in vitro conservation of $D$. crumenatum Sw. has been developed. Ex situ conservation methods played an important role in the conservation of plants. The main methods used in ex situ conservation are maintenance of living plants through cultivation, in vitro conservation, and encapsulation. An in vitro plant regeneration protocol was successfully established for medicinal species, Dendrobium crumenatum Sw. by culturing PLBs. Using this protocol, it is possible to produce viable uniform and healthy plants with a maximum survival rate that can be used for large scale cultivation. Furthermore, the protocol may facilitate the conservation of this fragrant, medicinal orchid in a natural population.

\section{Conclusions}

The data presented herein indicate that for rapid multiplication of $D$. crumenatum Sw. using different media could be effectively employed which otherwise exhibits extremely slow growth. MS medium containing $15 \% \mathrm{CW}$ gave the highest percentage of shooting and number of shoots per explant of 96.0 and 9.5 , respectively after 4 months of culture with a significant difference from other media. The addition of $0.2 \%(\mathrm{w} / \mathrm{v})$ AC significantly increased the number of leaves and roots. After 4 months of culture, PLBs developed into complete plantlets. MS medium supplemented with $15 \% \mathrm{CW}$ and $0.2 \%$ (w/v) AC and Vacin and Went (VW) medium supplemented with $15 \% \mathrm{CW}$ and $0.2 \%(\mathrm{w} / \mathrm{v}) \mathrm{AC}$ gave the highest number of roots per plantlet and root length at 5.3 roots and $34.9 \mathrm{~mm}$, respectively. After the transfer of rooted shoots to the greenhouse, $95 \%$ of the regenerated plantlets survived and grew vigorously. Plantlets grown in vitro were successfully acclimatized in the greenhouse and showed normal development.

\section{Acknowledgements}

This research was financially supported by Prince of Songkla University, Pattani Campus, Pattani, Thailand (Grant No. 59005). The authors would like to thank the Department of Technology and Industries, Faculty of Science and Technology, Prince of Songkla University, Pattani Campus, Pattani, Thailand, for providing laboratory facilities for this investigation.

\section{References}

[1] A Cronquist. An integrated system of classification of flowering plants. Columbia University Press, Ithaca, 1981, p. 248-50.

[2] RL Dressler. The orchids: Natural history and classification. Harvard University Press, Cambridge, 1981, p. 332.

[3] CJ Goh, MS Strauss and J Arditti. Floral induction and physiology in orchids. In: J Arditti (Ed.). Orchid biology: Reviews and prospectives. Cornell University Press, Ithaca, 1982, p. 213-41.

[4] RE Holttum. The story of the pigeon orchid. In: RE Holttum (Ed.). Plant life in Malaya. Longmans, UK, 1964, p 121-41.

[5] UM Sandrasagaran, S Subramaniam and V Murugaiyah. New perspective of Dendrobium crumenatum orchid for antimicrobial activity against selected pathogenic bacteria. Pak. J. Bot. 2014; 46, 719-24.

[6] U Meesawat and $\mathrm{K}$ Kanchanapoom. In vitro plant regeneration through embryogenesis and organogenesis from callus culture of pigeon orchid (Dendrobium crumenatum Sw.). Sci. Tech. Asia 2002; 7, 9-17.

[7] S Rittirat, K Thammasiri, S Kalawong and S Klaocheed. Ex-situ conservation of endangered medicinal Orchid species, Dendrobium crumenatum Sw. by micropropagation. In: Proceedings of the $13^{\text {th }}$ International Conference ASIAN Community Knowledge Networks for the Economy, Society, Culture, and Environmental Stability. Miyazaki, Japan, 2018, p. 46-52.

[8] T Murashige and F Skoog. A revised medium for rapid growth and bioassays with tobacco tissue cultures. Physiol. Plant. 1962; 15, 473-97.

[9] EF Vacin and FW Went. Some pH changes in nutrient solutions. Bot. Gaz. 1949; 110, 605-17. 
[10] JM Bonga and PV Aderkas. In vitro culture of trees. Kluwer Academic Publishers, Dordrecht, 1992 , p. 236.

[11] J Arditti and R Ernst. Micropropagation of orchids. Vol II. Wiley, New York, 1993, p. 1560.

[12] S Ichihashi and MO Islam. Effects of complex organic additives on callus growth in three orchid genera, Phalaenopsis, Doritaenopsis and Neofinetia. J. Jpn. Soc. Hortic. Sci. 1999; 68, 269-74.

[13] RLM Pierik, PA Sprenkels, B van der Harst and QG van der Meys. Seed germination and further development of plantlets of Paphiopedilum ciliolare Pfitz in vitro. Sci. Hortic. 1988; 34, 139-53.

[14] S Zeng, K Wu, JA Teixeira da Silva, J Zhang, Z Chen, N Xia and J Duan. Asymbiotic seed germination, seedling development and reintroduction of Paphiopedilum wardii Sumerh., an endangered terrestrial orchid. Sci. Hortic. 2012; 138, 198-209.

[15] Y Zhang, YI Lee, L Deng and S Zhao. Asymbiotic germination of immature seeds and the seedling development of Cypripedium macranthos Sw., an endangered lady's slipper orchid. Sci. Hortic. 2013; 164, 130-6.

[16] CC Chu and KW Mudge. Effects of prechilling and liquid suspension culture on seed germination of the yellow lady's slipper orchid (Cypripedium calceolus var. pubescens). Lindleyana 1994; 9 , 153-9.

[17] YI Lee, N Lee, EC Yeung and MC Chung. Embryo development of Cypripedium formosanum in relation to seed germination in vitro. J. Am. Soc. Hortic. Sci. 2005; 130, 747-53.

[18] KP Martin and J Madassery. Rapid in vitro propagation of Dendrobium hybrids through direct shoot formation from foliar explants, and protocorm-like bodies. Sci. Hortic. 2006; 108, 95-9.

[19] B Pant and R Gurung. In vitro seed germination and seedling development in Aerides odorata Lour. J. Orchid Soc. India. 2005; 19, 51-5.

[20] SK Bhadra and MM Hossain. Introduction of embryogenesis and direct organogenesis in Micropera pallida Lindl. An epiphytic orchid of Bangladesh. J. Orchid Soc. India. 2004; 18, 5-9.

[21] S Pradhan. 2007, Ex situ conservation of two orchid species viz. Cymbidium elegans Lindl. and Dendrobium densiflorium Lindl. by tissue culture technique. Ph.D. Dissertation, Central Dept Bot TU Kathmandu, Nepal.

[22] S Asghar, T Ahmad, IA Hafiz and M Yaseen. In vitro propagation of orchid (Dendrobium nobile) var. Emma White. Afr. J. Biotechnol. 2011; 10, 3097-103.

[23] NV Ket, EJ Hahn, SY Park, D Chakrabarty and KY Peak. Micropropagation of an endangered orchid Anoectochilus formosanus. Biol. Plant. 2004; 48, 339-44.

[24] E Dumas and O Monteuuis. In vitro rooting of micropropagated shoots from juvenile and mature Pinus pinaster explants-influence of activated charcoal. Plant Cell Tiss. Org. Cult. 1995; 40, 231-5.

[25] G Fridborg, ML Pedersen and T Eriksson. The effect of activated charcoal on tissue cultures: Adsorption of metabolites inhibiting morphogenesis. Physiol. Plant. 1987; 43, 104-6.

[26] G Fridborg and T Eriksson. Effects of activated charcoal on morphogenesis in plant tissue cultures. Physiol. Plant. 1975; 34, 306-8.

[27] MJ Constantin, RR Henke and MA Mansur. Effect of activated charcoal on callus growth and shoot organogenesis in tobacco. Vitro Cell Dev. Biol. Plant. 1977; 13, 287-93.

[28] SJ Nissen and EG Sutter. Stability of IAA and IBA in nutrient medium to several tissue culture procedures. Hortic. Sci. 1990; 25, 800-2.

[29] MA Weatherhead, J Burdon and GG Henshaw. Some effects of activated charcoal as an additive to plant tissue culture media. Z Pflanzenphysiol. 1978; 89, 141-7.

[30] R Ernst. The use of activated charcoal in asymbiotic seedling culture of Paphiopedilum. Am. Orchid Soc. Bull. 1974; 43, 35-8.

[31] R Ernst. Studies in asymbiotic culture of orchids. Am. Orchid Soc. Bull. 1975; 44, 12-8.

[32] L Johansson, E Galleberg and A Gedin. Correlation between activated charcoal, Fe EDTA and other organic media ingredients in cultures of anthers of Anemone canadensis. Physiol. Plant. 1990; 80, $243-9$.

[33] J Van Huylenbroeck, A Piqueras and P Debergh. Photosynthesis and carbon metabolism in leaves formed prior and during ex vitro acclimatization of micropropagated plants. Plant Sci. 1998; 134, 21-30. 
[34] LP Diaz, JJ Namur, SA Bollati and OEA Arce. Acclimatization of Phalaenopsis and Cattleya obtained by micropropagation. Rev. Colomb. Biotecnol. 2010; 12, 27-40.

[35] EF George and PC Debergh. Micropropagation: Uses and methods. In: EF George, MA Hall and GJ de Klerk (Eds.). Plant propagation by tissue culture. $3^{\text {rd }}$ eds. Springer, Dordrecht, Netherlands, 2008, p. 29-64.

[36] S Chugh, S Guha and IU Rao. Micropropagation of orchids: A review on the potential of different explants. Sci. Hort. 2009; 22, 507-20. 